\title{
ЕКОНОМІКО-МАТЕМАТИЧНЕ МОДЕЛЮВАННЯ
}

\author{
УДК 330.59: 519.237 \\ JEL: I31; C89
}

\author{
(C) Budko O.N., Bakhar S.V., 2021 \\ budko_on@mail.ru, baharsergey291097@gmail.com \\ Yanka Kupala State University of Grodno, Grodno, Belarus
}

\section{MULTIDIMENSIONAL STATISTICAL ANALYSIS OF THE STANDARD OF LIVING OF THE POPULATION OF BELARUS}

\begin{abstract}
У статті на основі авторської системи показників проведено порівняльний аналіз рівня життя населення в адміністративних районах та обласних иентрах Білорусі за 2019 рік. За допомогою методу головних компонент факторного аналізу виявлено показники, які найбільшою мірою впливають на рівень життя, обчислено інтегральний показник (індекс) рівня життя населення, побудовано та проаналізовано рейтинг районів та обласних иентрів. Дано рекомендації щчодо поліпшення рівня життя. Методом k-середніх кластерного аналізу сформовано п'ять кластерів зі схожим рівнем життя населення. Проведено аналіз сформованих кластерів як за середніми значеннями показників, так і по районах областей. Зроблено висновок про те, щуо за рівнем життя в 2019 рочі лідирувала Брестська область.
\end{abstract}

Ключові слова: рівень життя, інтегральний показник, метод головних компонент, рейтинг, кластерний аналіз.

Formulation of the problem. In the Republic of Belarus, as in other countries of the near and far abroad, close attention is paid to improving the standard of living of the population. The standard of living of the population is a complex socioeconomic category that reflects the degree of satisfaction of people with material and non-material goods and services. The republic has developed the country's sustainable development Goals, which are aimed at improving the socio-economic situation of the State. Among them are goals related to improving the standard of living of the population. This is Goal 8-Decent work and economic growth; Goal 10-reduce inequality; Goal 11-sustainable cities and human settlements [1]. Thus, the assessment and comparative analysis of the standard of living in different regions of the republic will identify the leading and lagging regions and provide information for the development of corrective measures.

Analysis of recent sources and publications. Close to the concept of "standard of living" is the concept of "quality of life". They have a lot in common, but they also have significant differences. The standard of living of the population is characterized by the degree (magnitude) of consumption of specific goods, provision of various services and the significance of satisfaction of the population with spiritual values. The concept of "quality of life" indicates, first of all, a set of essential features, properties, and features that distinguish the lives of representatives of various

socio-demographic groups and the population as a whole.

Among the countries of the world, the standard of living in Belarus is at an average level - 37th place [2]. In 2019, our country was ranked in the top 100 best countries in the world in terms of living standards, and there is a positive trend in this direction.

The development of a general indicator of the standard of living of the population is one of the most important tasks of all international statistics. As a generalizing indicator, the following were proposed:: real wage index, subsistence minimum index, cost of living index. Each of these indicators is valuable, but they do not provide a comprehensive description of the standard of living. For more information about the differences between the concepts of "standard of living" and "quality of life", and the ways of their assessment, see, for example, [3-4]. Most often, the arithmetic mean of several indices is taken as a generalizing indicator, or expert assessments of the comparative importance of individual indicators or indices are used. Thus, there is no single approach to assessing the standard of living of the population of the state, individual groups of the population.

Currently, the UN Statistical Commission recommends the following groups of indicators to assess the standard of living of the population [5]:

- demographic characteristics of the population (birth rate, mortality, morbidity, life expectancy);

- indicators of the population's income (real and nominal); 
- indicators of expenses and savings;

- indicators of consumption of material goods and services by the population;

- indicators of the population's availability of housing and durable goods;

- employment and unemployment indicators;

- indicators of working conditions of the population;

- indicators of free time;

- indicators of education, health, culture, physical education and sports, tourism and recreation.

It is these recommendations of the UN Statistical Commission that are taken into account when forming a system of indicators for assessing the standard of living of the population of Belarus in this article, taking into account the availability and availability of relevant statistical information.

The aim of the article - to conduct a comparative analysis of the standard of living of the population in the administrative districts and regional centers of Belarus in 2019 using the methods of multivariate statistical analysis.

Presentation of the main results of the study. The initial data were selected from the statistical yearbooks of all six regions of Belarus for 2019 [611]. In [12-13], a system of 15 indicators was used to analyze the standard of living in different regions of Belarus. The analysis of the composition of the main factors and the ratings made it possible to optimize the system and identify 11 indicators in six groups. Thus, the indicator system used has the form:

\section{population:}

1. Demographic characteristics of the

$\mathrm{X} 1$ - the total birth rate per 1000 people of the district population;

$\mathrm{X} 2$ - the total mortality rate per 1000 people.

2. Indicators of income of the population.

$\mathrm{X} 3$-average nominal salary, rub.

3. Indicators of housing security of the population:

X4 - the number of apartments built per 1000 people. population.

4. Employment and unemployment indicators:

X5-the share of the employed population, \%;

X6 - the registered unemployment rate (at the end of the year), as a percentage of the employed population.

\section{Education indicators}

$\mathrm{X} 7$ - the number of children in pre-school education institutions (UDO) per 1000 people.;

X8 - the number of students in general secondary education institutions (GES) per 1000 people.

\section{Health indicators:}

X9 - number of beds per 10000 people.;

$\mathrm{X} 10$-provision of the population with practicing doctors per 10000 people.;

$\mathrm{X} 11$ - provision of the population with average medical workers per 10000 people.

We emphasize that the proposed system of indicators is far from perfect and can be supplemented if there are statistical data.

The applied research methodology is not new and is based on the consolidation of a system of indicators that characterize different aspects of the standard of living in each district into one integral indicator (index). There are many ways to do this. Most often, expert assessments are used. This approach is based on the use of methods of multivariate statistical analysis [14]. First, the dimension of the indicator system is reduced by the method of principal components of factor analysis, and it is replaced by a certain number of principal factors. The main factors form groups of baseline indicators that are closely related to each other. An integral indicator (index) is a linear combination of the values of the main factors, where the percentages of the variance of the indicators explained by each main factor are used as weights. The rating is based on the integral indicator. Analyzing the values of the main factors, you can identify what allowed or did not allow you to take a particular position in the rating. This approach to the construction of an integral indicator can be applied not only to the construction of an integral indicator of the standard of living of the population.

Before applying the principal component method, the initial data is reduced to a scale, for example, $[0,1]$ and to one direction of influence on the integral indicator. There are many ways to do this. The following formulas were used: (2) for indicators X2 and X6, and formula (1) for normalizing the remaining indicators.

$$
\begin{aligned}
& x_{i}^{\text {norm }}=\left(x_{i}-x_{\min }\right) /\left(x_{\max }-x_{\min }\right), \quad i=\overline{1,58,} \\
& x_{i}^{\text {norm }}=\left(x_{\max }-x_{i}\right) /\left(x_{\max }-x_{\min }\right), \quad i=\overline{1,58,}
\end{aligned}
$$


where $x_{i}, x_{i}^{\text {norm }}-$ non-normalized and normalized value of the $i$-th indicator, $x_{\max }, x_{\min }$ - its maximum and minimum values.

The main calculations were carried out in the package Statistica.

Building an integral indicator of the standard of living and rating of districts. The initial data for the districts of all regions (124 objects) were normalized and brought to one direction ("the more, the better») according to formulas (1) and (2).
Using the rotation of the main factors of Varimax normalized, the normalized indicators were converted into four main factors, which explain $78.07 \%$ of the total variance of all indicators. Table 1 shows the factor loads of each source variable on the main factors, sorted in each main factor by significant loads. As a result of the rotation, the retained variance was slightly redistributed between the factors.

Factor loadings and main factor variances *

\begin{tabular}{|c|c|c|c|c|}
\hline Indicators & Factor 1 & Factor 2 & Factor 3 & Factor 4 \\
\hline X3 & $\mathbf{0 , 8 6 0}$ & 0,137 & 0,063 & $-0,251$ \\
\hline X2 & $\mathbf{0 , 8 2 4}$ & 0,232 & 0,006 & 0,169 \\
\hline X7 & $\mathbf{0 , 7 4 8}$ & 0,044 & $-0,126$ & 0,302 \\
\hline X4 & $\mathbf{0 , 6 5 1}$ & $-0,020$ & 0,146 & 0,008 \\
\hline X11 & $-0,022$ & $\mathbf{0 , 9 3 5}$ & $-0,022$ & 0,079 \\
\hline X9 & 0,073 & $\mathbf{0 , 8 7 0}$ & 0,039 & $-0,183$ \\
\hline X10 & 0,413 & $\mathbf{0 , 7 7 1}$ & 0,065 & $-0,168$ \\
\hline X6 & 0,004 & $-0,021$ & $\mathbf{0 , 9 5 4}$ & $-0,168$ \\
\hline X5 & 0,120 & 0,075 & $\mathbf{0 , 9 3 2}$ & $-0,216$ \\
\hline X8 & 0,033 & $-0,081$ & $-0,122$ & $\mathbf{0 , 9 2 1}$ \\
\hline X1 & 0,105 & $-0,111$ & $-0,272$ & $\mathbf{0 , 7 5 4}$ \\
\hline Stored variance, \% & 23,68 & 21,15 & 17,40 & 15,84 \\
\hline Accumulated variance, & 23,68 & & & 78,07 \\
\hline$\%$ & & 44,83 & 62,23 & \\
\hline
\end{tabular}

* Source: developed by the authors

Thus, according to Table 3.1, the first major factor accounts for approximately $23.7 \%$ of the total variance, the second for $21.2 \%$, the third major factor for $17.4 \%$, and the fourth major factor for $15.8 \%$ of the total variance. This means that the indicators of the first main factor, then the second, third and fourth, have the greatest impact on the standard of living of the population.

The first main factor was the following indicators: income of the population $\mathrm{X} 3$, one of the indicators of demographic characteristics of the population - the mortality rate $\mathrm{X} 2$, one of the indicators of education - the number of children in UDO X7, as well as the indicator of housing security $\mathrm{X} 4$.

The second main factor was formed by the health indicators X9-X11.
The third main factor is formed by the indicators of employment and unemployment X5-X6.

The fourth main factor was the education index $\mathrm{X} 8$ - the number of students in the UOS and the demographic characteristics of the population X1 the total birth rate.

Thus, the greatest impact on the standard of living of the population in the regions of the Republic of Belarus in 2019 was exerted by the following indicators: income of the population X3, one of the indicators of demographic characteristics of the population - the mortality rate $\mathrm{X} 2$, one of the indicators of education - the number of children on parole X7 and the indicator of housing security X4.

Then, using the formula (3), the integral indicators (indices) of the standard of living of the population for the districts of the republic of the standard of living for each district were calculated. 


$$
R_{i}=23,68 \cdot F_{1, i}+21,15 \cdot F_{2, i}+17,40 \cdot F_{3, i}+15,84 \cdot F_{4, i}, \quad i=\overline{1,124}
$$

where $R_{\mathrm{i}}$ - integral indicator of the standard of percentage of the preserved variance corresponding living of the population of the $i$-th district, $F_{1, i}, F_{2, i}$, $F_{3, i}, F_{4, i}$ - the values of the main factors of the $i$-th district, the coefficients for the factors are the to the main factors from Table 1.

Table 2 shows a fragment of the district rating table. The data is sorted in descending order of the integral indicator of the standard of living $(\mathrm{R})$.

Table 2

A fragment of the rating of the districts of Belarus by the integral indicator and the values of the main factors *

\begin{tabular}{|c|c|c|c|c|c|c|c|}
\hline \multirow{2}{*}{ District } & \multirow{2}{*}{ Region } & \multirow{2}{*}{$\begin{array}{l}\text { Place } \\
\text { in the } \\
\text { rating } \\
\text { by R }\end{array}$} & \multirow{2}{*}{$\mathrm{R}$} & \multicolumn{4}{|c|}{$\begin{array}{l}\text { Place in the rating according to the } \\
\text { values of factors }\end{array}$} \\
\hline & & & & $\begin{array}{c}\text { Factor } \\
1\end{array}$ & $\begin{array}{l}\text { Factor } \\
2\end{array}$ & $\begin{array}{l}\text { Factor } \\
3\end{array}$ & $\begin{array}{c}\text { Factor } \\
4\end{array}$ \\
\hline City of Brest & Brest & 1 & 116,93 & 9 & 8 & 7 & 19 \\
\hline City of Grodno & Grodno & 2 & 115,66 & 7 & 10 & 36 & 24 \\
\hline Ostrovets & Grodno & 3 & 101,52 & 6 & 32 & 2 & 18 \\
\hline City of Minsk & Minsk & 4 & 95,28 & 1 & 22 & 1 & 119 \\
\hline Soligorsk & Minsk & 5 & 94,43 & 4 & 14 & 55 & 70 \\
\hline Brest & Brest & 6 & 87,28 & 48 & 2 & 6 & 15 \\
\hline City of Mogilev & Mogilev & 7 & 84,85 & 13 & 3 & 43 & 45 \\
\hline Pinsk & Brest & 8 & 84,78 & 19 & 12 & 37 & 6 \\
\hline City of Vitebsk & Vitebsk & 9 & 63,97 & 14 & 6 & 84 & 94 \\
\hline Stolin & Brest & 10 & 55,07 & 82 & 61 & 5 & 1 \\
\hline Grodno & Grodno & 11 & 51,66 & 35 & 9 & 14 & 104 \\
\hline Baranovichi & Brest & 12 & 48,82 & 18 & 29 & 27 & 31 \\
\hline$\ldots$ & $\ldots$ & $\ldots$. & $\ldots$ & & $\ldots$ & $\ldots$ & $\ldots$ \\
\hline Beshenkovichi & Vitebsk & 111 & $-42,86$ & 99 & 89 & 87 & 117 \\
\hline Rogachev & Gomel & 112 & $-43,95$ & 54 & 51 & 116 & 84 \\
\hline Svetlogorsk & Gomel & 113 & $-45,39$ & 24 & 83 & 118 & 110 \\
\hline Yelsk & Gomel & 114 & $-49,40$ & 72 & 69 & 119 & 44 \\
\hline Vetka & Gomel & 115 & $-50,60$ & 67 & 41 & 124 & 49 \\
\hline Korelichi & Grodno & 116 & $-52,91$ & 120 & 55 & 92 & 122 \\
\hline Sharkovshchinsk & Vitebsk & 117 & $-54,77$ & 123 & 80 & 96 & 92 \\
\hline Liozno & Vitebsk & 118 & $-55,98$ & 89 & 110 & 93 & 121 \\
\hline Gorodok & Vitebsk & 119 & $-64,90$ & 110 & 111 & 86 & 123 \\
\hline Oktyabrsk & Gomel & 120 & $-65,92$ & 109 & 107 & 104 & 69 \\
\hline Buda-Koshelev & Gomel & 121 & $-78,36$ & 86 & 119 & 111 & 83 \\
\hline Glussk & Mogilev & 122 & $-86,21$ & 77 & 124 & 25 & 52 \\
\hline Dobrush & Gomel & 123 & $-87,36$ & 65 & 116 & 122 & 103 \\
\hline Loev & Gomel & 124 & $-87,51$ & 97 & 64 & 123 & 118 \\
\hline
\end{tabular}

* Source: developed by the authors

Table 2 shows that in 2019, the districts with the highest standard of living (according to the indicator system used) were: Brest, Grodno, Ostrovetsky district (Grodno region), Minsk and Soligorsky district (Minsk region), Brest district, Mogilev, Pinsky district (Brest region), Vitebsk, Stolinsky district (Brest region). Gomel (21 positions) and Minsk (63 positions) are slightly lower. Moreover, 
the city of Minsk has the value of the integral indicator and its position in the rating indicates that the standard of living in it is at an average level according to the considered system of indicators.

The lowest standard of living of the population in 2019 was observed in Vetkovsky (Gomel region), Korelichsky (Grodno region), Sharkovshchinsky, Lioznensky and Gorodoksky (Vitebsk region), Oktyabrsky and Buda-Koshelevsky (Gomel region), Glussky (Mogilev region), Dobrushsky and Loyevsky (Gomel region) districts.

According to the column of rating values for each main factor in Table 3.2, you can separately characterize the position of each district according to the indicators that formed this main factor, and give some recommendations.

Thus, the city of Brest occupies high positions in terms of the first, second and third main factors, but the nineteenth position in terms of the fourth main factor. Therefore, the indicator X8 - the number of children in the USO, as well as the indicator X1 the total fertility rate, need to be improved.

The second position in the rating is occupied by the city of Grodno. The recommendation is to improve the indicators of the third (36th place) and fourth (24th place) main factors, namely the indicators of employment and unemployment, one of the indicators of education - the number of students in the UOSO (X8), as well as the overall birth rate (X1).

The third position is occupied by the Ostrovetsky district. The recommendation is to improve the indicators of the second and fourth main factors.

The fourth position in the rating was taken by the Minsk district. It occupies the 22 nd position in terms of the second main factor and the 119th position in terms of the fourth main factor.

The city of Mogilev occupies the seventh position in this rating. It is recommended to improve the values of the indicators that formed the third main factor (43rd place) and the fourth main factor (45th place).

The city of Vitebsk, which occupies the ninth position in the rating, as well as the city of Mogilev, is recommended to improve the value of the indicators that formed the third (84th place) and fourth (94th place) main factors.

The city of Gomel is placed on 21 positions. It is also recommended to improve the values of the indicators of the third (106th place) and fourth (107th place) main factors, as well as Mogilev and Vitebsk.

In 2019, the city of Minsk took the 63rd place in the rating of districts according to the integral indicator. Recommendations: to improve the value of indicators in the second (25th place), third (102nd place) and fourth (124th place) main factors, namely, to improve the value of health indicators (X9-X11), employment and unemployment indicators (X5-X6), as well as the indicator X8 - the number of students in the USO and the indicator X1 - the total birth rate.

Such districts as: Lioznensky, Gorodoksky, Oktyabrsky, Buda-Koshelevsky, Glussky, Dobrushsky, Loevsky, etc. need to improve all indicators.

Similarly, each district can be reviewed and recommended.

Cluster analysis of the standard of living of the population of Belarus. Using the cluster analysis procedure - the k-means method, all the districts of the republic were divided into groups that were homogeneous in terms of the integral indicator into five significantly different clusters. The number of clusters is set by the user. This is usually 3 or 5 clusters, depending on the number of objects and the results of clustering. In our case, we identified 5 clusters with significantly different mean values of the integral index R, which was established using the Scheffe criterion. Since $p<10-7<0.05$, it can be argued that the average values of the integral indicator in the clusters are significantly different and the division of districts into five clusters is reasonable; the entire set of districts can be divided into a much larger number of reliably different clusters, if necessary.

As a result of calculations, the first cluster was formed by 8 objects with a high standard of living: Brest, Grodno, Ostrovetsky, Minsk, Soligorsky, Brest districts, Mogilev and Pinsky district. This is the top of the ranking from Table 2.

The second cluster with the standard of living of the population above the average level formed 20 objects: Vitebsk, Stolinsky, Grodno, Baranovichi, Mogilev, Krasnopol, Berezovsky, Ivanovo, Luninetsky, Kobrin, Lida, Slutsk districts, Gomel, Derzhinsky, Maloritsky, Zhabinkovsky, Vitebsk, Starodorozhsky, Kostyukovichi, Molodechensky districts.

The third cluster is formed by objects with an average standard of living, a total of 36 objects. It includes: Lyakhovichi, Kamenetsky, Smorgon, Volkovysk, Oshmyansky, Nesvizh, Gantsevichi, Uzdensky, Shklovsky, Borisovsky, Kruglyansky, Narovlyansky, Krichevsky, Slonimsky, Bobruisk, Ivatsevichsky, Lubansky, Orshansky, Chechersky, Voronovsky, Berezensky, Stolbtsovsky, Zhlobinsky, Slavgorodsky, Mozyrsky, Drogichinsky, Lepelsky, Smolevichsky, Pruzhansky, Cherikovsky, Logoysky, Gomel, Braginsky, Krupsky, Minsk and Osipovichi districts. 
The fourth cluster consisted of 46 objects with a below-average standard of living. It was formed by: Polotsk, Miorsky, Klimovichi, Chashniksky, Kletsky, Mostovsky, Ivyevsky, Kormyansky, Khoinitsky, Glubokoye, Lelchitsky, Dribinsky, Shchuchinsky, Kalinkovichi, Svislochsky, Zelvinsky, Shumilinsky, Belynichsky, Goretsky, Novogrudsky, Khotimsky, Berestovitsky, Vileysky, Chervensky, Bykhovsky, Myadelsky and other districts.
The fifth cluster is formed by 14 objects with a low standard of living: Beshenkovichi, Rogachevsky, Svetlogorsk, Yelsky, Vetkovsky, Korelichsky, Sharkovshchinsky, Lioznensky, Gorodoksky, Oktyabrsky, Buda-Koshelevsky, Glussky, Dobrushsky and Loevsky districts.

Next, it is logical to answer the question in which area of Belarus the standard of living is higher. For this purpose, Table 3 of the distribution of the districts of the regions by cluster was constructed.

Table 3

Distribution of regional districts by cluster, units *

\begin{tabular}{|l|c|c|c|c|c|}
\hline \multirow{2}{*}{\multicolumn{1}{c|}{ Region }} & \multicolumn{5}{c|}{ Clusters } \\
\cline { 2 - 6 } & 1 & 2 & 3 & 4 & 5 \\
\hline Brest & 3 & 8 & 6 & - & - \\
\hline Vitebsk & - & 2 & 2 & 14 & 4 \\
\hline Gomel & - & 1 & 6 & 7 & 8 \\
\hline Grodno region & 2 & 2 & 5 & 8 & 1 \\
\hline Minsk & 2 & 4 & 10 & 7 & - \\
\hline Mogilev & 1 & 3 & 7 & 10 & 1 \\
\hline Total & 8 & 20 & 36 & 46 & 14 \\
\hline
\end{tabular}

* Source: developed by the authors

Some conclusions can be drawn from Table 3, but it is impossible to compare the number of districts in each cluster, since each region consists of a different number of districts: from 17 (Brest region) to 23 (Minsk region). So let's go to the percentage distribution of districts and display it graphically.
Figure 1 shows that the majority of the republic's districts $(66 \%)$ fall into cluster 3 and 4 with an average and below-average standard of living. Above the average standard of living in $16 \%$ of the districts (cluster 2), high - in 7\% (cluster 1), low - in $11 \%$ (cluster 5 ) of the districts of the republic.

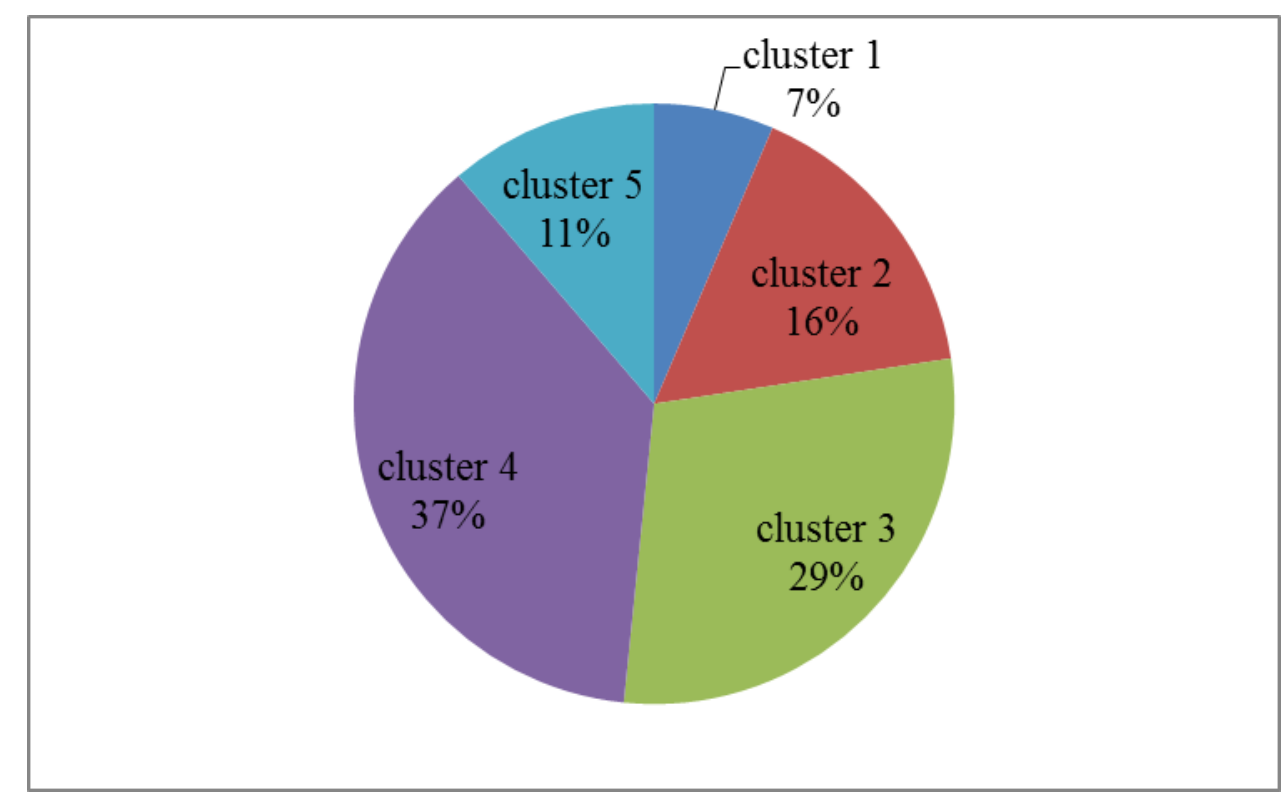

Fig. 1. Distribution of districts of Belarus in clusters according to the standard of living of the population *

* Source: developed by the authors 
In Figure 2, you can see how the regions of the regions in each cluster are distributed. It is obvious that the leader in terms of the standard of living of the population in 2019 was the Brest region, which has the largest share of districts in clusters 1 and 2 with a high and above-average standard of living of the population and there are no districts in clusters 4 and 5 with a below-average and low standard of living. The last positions in terms of living standards are shared by the Vitebsk and Gomel regions. The Minsk region occupies the second position in terms of living standards. Grodno and Mogilev regions generally occupy an intermediate position, they can be assigned the $3 \mathrm{rd}$ and 4th position among the regions of the republic.

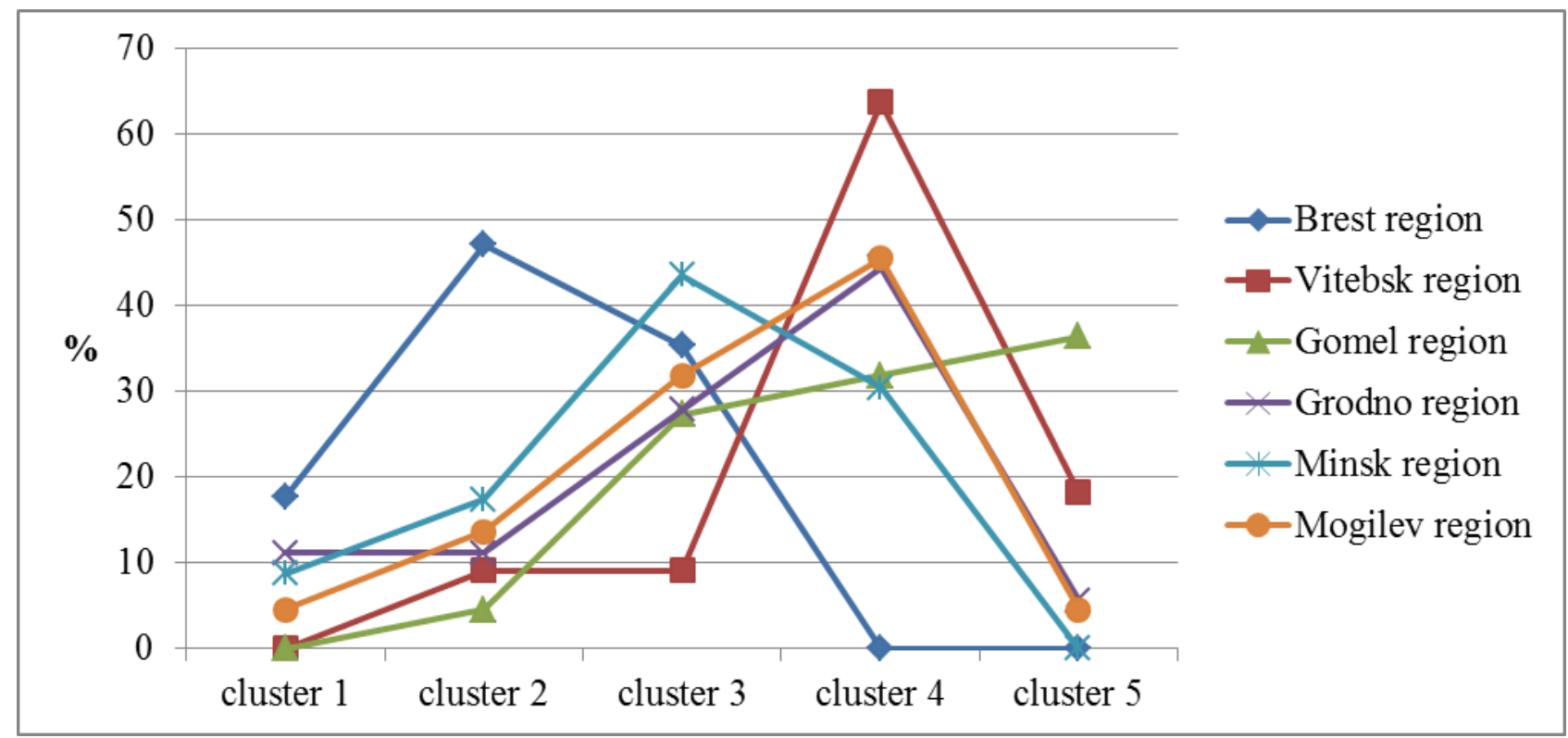

Fig. 2. Distribution of districts of regions in clusters by the standard of living of the population *

* Source: developed by the authors

For a more reliable distribution of places according to the standard of living of the population between the regions, it is possible to estimate the standard of living in the regions of Belarus and conduct a comparative analysis using, for example, panel data.

Let's analyze the average values of the initial indicators in the clusters, presented in Table 4.

Average values of the initial indicators in the clusters *

\begin{tabular}{|c|c|c|c|c|c|c|}
\hline Clusters & $\begin{array}{c}\text { Total } \\
\text { fertility rate } \\
\text { per 1000 } \\
\text { people } \\
\text { population }\end{array}$ & $\begin{array}{c}\text { The general } \\
\text { mortality } \\
\text { rate per } \\
1000 \\
\text { people } \\
\text { population }\end{array}$ & $\begin{array}{c}\text { Average } \\
\text { nominal } \\
\text { salary, } \\
\text { rubles }\end{array}$ & $\begin{array}{c}\text { Number of } \\
\text { apartments } \\
\text { built per } \\
1000 \\
\text { people } \\
\text { population }\end{array}$ & $\begin{array}{c}\text { Share of } \\
\text { the } \\
\text { employed } \\
\text { populatio } \\
\mathrm{n}, \%\end{array}$ & $\begin{array}{c}\text { Registered } \\
\text { unemployment rate (at } \\
\text { the end of the year), } \\
\text { of the employed } \\
\text { population }\end{array}$ \\
\hline Cluster 1 & $\mathrm{X}_{1}$ & $\mathrm{X}_{2}$ & $\mathrm{X}_{3}$ & $\mathrm{X}_{4}$ & $\mathrm{X}_{5}$ & $\mathrm{X}_{6}$ \\
\hline Cluster 2 & 10,66 & 10,86 & 1092,90 & 9,90 & 49,81 & 0,21 \\
\hline Cluster 3 & 10,28 & 14,70 & 890,24 & 5,04 & 41,15 & 0,27 \\
\hline Cluster 4 & 9,60 & 16,00 & 885,29 & 4,17 & 36,32 & 0,42 \\
\hline Cluster 5 & 9,69 & 19,62 & 801,36 & 3,06 & 35,49 & 0,44 \\
\hline
\end{tabular}

\begin{tabular}{|c|l|l|l|l|l|}
\hline \multirow{4}{*}{ Clusters } & $\begin{array}{l}\text { Number of } \\
\text { children on } \\
\text { parole per }\end{array}$ & $\begin{array}{l}\text { The number of } \\
\text { students in the }\end{array}$ & $\begin{array}{l}\text { Number of } \\
\text { beds per }\end{array}$ & $\begin{array}{l}\text { Provision of } \\
\text { practicing doctors } 1000\end{array}$ & $\begin{array}{l}\text { Provision of the } \\
\text { population with } \\
\text { paramedical }\end{array}$ \\
& $\begin{array}{l}1000 \text { people } \\
\text { population, }\end{array}$ & $\begin{array}{l}\text { people } \\
\text { population }\end{array}$ & $\begin{array}{l}\text { people } \\
\text { population }\end{array}$ & $\begin{array}{l}\text { per 10000 } \\
\text { population }\end{array}$ & $\begin{array}{l}\text { workers per 10000 } \\
\text { population }\end{array}$ \\
\cline { 2 - 5 }
\end{tabular}




\begin{tabular}{|c|c|c|c|c|c|}
\hline & people & & & & \\
\cline { 2 - 6 } & $\mathrm{X}_{7}$ & $\mathrm{X}_{8}$ & $\mathrm{X}_{9}$ & $\mathrm{X}_{10}$ & $\mathrm{X}_{11}$ \\
\hline Cluster 1 & 49,25 & 116,29 & 96,04 & 52,84 & 143,38 \\
\hline Cluster 2 & 44,56 & 115,60 & 78,93 & 36,54 & 122,77 \\
\hline Cluster 3 & 42,44 & 111,14 & 72,56 & 29,67 & 114,24 \\
\hline Cluster 4 & 37,80 & 105,91 & 72,87 & 24,75 & 111,58 \\
\hline Cluster 5 & 36,74 & 103,08 & 65,50 & 24,23 & 96,10 \\
\hline
\end{tabular}

* Source: developed by the authors

Table 4 shows that, with rare exceptions, the best average values of indicators are observed in cluster 1 and deteriorate towards cluster 5 . We will cancel out that only 2 of the indicators considered, the smaller, the higher the standard of living - these are $\mathrm{X} 2$ and $\mathrm{X} 6$, the rest - the larger, the higher the standard of living of the population.

However, some indicators in different clusters are very different. So, comparing the average values of indicators in cluster 1 with a high standard of living and in cluster 5 with a low standard of living of the population, we come to the conclusions:

- the mortality rate (X2) in cluster 1 is almost 2 times less than in cluster 5 ;

- the average nominal salary (X3) is 1.4 times higher in cluster 1 ;

- the number of apartments built (X4) in cluster 1 is 3.8 times more than in cluster 5;

- the share of the employed population (X5) is 2.4 times higher in cluster 1 ;

- the unemployment rate (X6) is almost 5 times lower in cluster 1 as opposed to cluster 5 ;

- the provision of the population with practicing doctors $(\mathrm{X} 10)$ in cluster 1 is more than 2 times higher.

Conclusions. Thus, using the methods of multivariate statistical analysis, integral indicators and the rating of districts and regional centers of Belarus in terms of the standard of living of the population in them were constructed; indicators that most affect the standard of living were identified; recommendations were given on which indicators should be improved first, regardless of high or low place in the rating; five clusters were formed, objects in which have similar values of the integral indicator: with high, above average, average, below average and low standard of living; the average values of the initial indicators in the clusters are analyzed and some features are identified; conclusions about the standard of living of the population in the regions (regions) of Belarus are made on the basis of the distribution of the districts of the regions by clusters.

The method used does not depend on the content of the problem under study and can be used for spatial or panel data, when it is necessary to collapse a number of indicators into one integral one without using expert estimates.

The results obtained are largely determined by the chosen system of indicators for the analysis of a certain problem. The meaningful formation of the system of indicators is a large preliminary work that lies outside the framework of the calculation methodology used.

The development of the topic is seen in the following directions:

- improvement of the system of indicators for assessing the standard of living of the population;

- it is interesting to compare the results obtained for 2019 with previous periods, for example, for 2014 or 2015.

\section{Список літератури}

1. Цели устойчивого развития в Беларуси. URL: https://sdgs.by/targets// (дата звернення 11.02.2021).

2. Индекс качества жизни по странам, 2020. URL: https://www.numbeo.com/quality-oflife/rankings_by_country.jsp?title=2019\&displayColumn=0 (дата звернення 05.03.2021).

3. Андреева О.Н. Уровень и качество жизни: содержание понятий и их составляющие. URL: https:/cyberleninka.ru/article/v/uroven-i-kachestvo-zhizni-soderzhanie-ponyatiy-i-ih-sostavlyayuschie (дата звернення 01.02.2020).

4. Андреева О.Н. Способь оценки уровеня и качества жизни населения. URL: https://cyberleninka.ru/article/n/sposoby-otsenki-urovnya-i-kachestva-zhizni-naseleniya (дата звернення 01.02.2020).

5. Система показателей уровня $u$ качества жизни населения. URL: https://www.vvsu.ru/analytic/article/10651389/ (дата звернення 20.01.2021).

6. Статистический ежегодник Гродненской области, 2020. URL: https://grodno.belstat.gov.by/ofitsialnaya-statistika/publications/public_compilation/index_18036 (дата звернення 15.10.2020). 
7. Статистический ежегодник Брестской области, 2020. URL: https://brest.belstat.gov.by/ofitsialnayastatistika/publications/public_compilation/index_18060/(дата звернення 18.10.2020).

8. Статистический ежегодник Витебсккй области, 2020. URL: https://vitebsk.belstat.gov.by/ofitsialnayastatistika/publications/public_compilation/index_18040/ (дата звернення 21.10.2020).

9. Статистический ежегодник Гомельской области, 2020. URL: https://gomel.belstat.gov.by/ofitsialnayastatistika/publications/public_compilation/index_18043/ (дата звернення 24.10.2020).

10. Статистический ежегодник Минской области, 2020. URL: https://minsk.belstat.gov.by/ofitsialnayastatisticheskaya-informatsiya/publications/public_compilation/index_18073/ (дата звернення 27.10.2020).

11. Статистический ежегодник Могилевской области, 2020. https:/mogilev.belstat.gov.by/ofitsialnaya-statistika/publications/public_compilation/index_18039 (дата звернення 30.10.2020).

12. Будько О.Н. Система показателей и анализ уровня жизни населения. Фінанси, банківська система та страхування в Україні: стан, проблеми та перспективи розвитку в кризовїй економічі: збірник наук. праць за матеріалами Міжнар. науково-практичної інтернет-конф., 21-22 березня 2019 р. ДДАЕУ, 2019. С. 166-168.

13. Бахарь С.В. Сравнительный анализ уровня жизни населения в западных регионах Беларуси. Интеграция практики и теории научного знания: материалы VII научно-практической конференции с международным участием Северо-Западного института (филиала) АНО ВО МГЭУ// 7 февраля 2020 г. Мурманск. - М.: МГЭУ, 2020. С. 11-15.

14. Ким Дж.-О., Мьюллер Ч.У., Клекка У.Р. Факторный, дискриминантныи и кластерный анализ. Финансы и статистика, 1989. - 215 с.

\section{References}

1. Sustainable Development Goals in Belarus (2018), available at: https://sdgs.by/targets// (Accessed 11.02.2021).

2. Quality of life index by country (2020), available at: https://www.numbeo.com/quality-oflife/rankings_by_country.jsp?title=2019\&displayColumn=0 (Accessed 05.03.2021).

3. Andreeva, O.N. (2012), The level and quality of life: the content of concepts and their components, available at: https:/cyberleninka.ru/article/v/uroven-i-kachestvo-zhizni-soderzhanie-ponyatiy-i-ih-sostavlyayuschie (Accessed 01.02.2020).

4. Andreeva, O.N. (2013), Methods for assessing the level and quality of life of the population, available at: https://cyberleninka.ru/article/n/sposoby-otsenki-urovnya-i-kachestva-zhizni-naseleniya (Accessed 01.02.2020).

5. The system of indicators of the level and quality of life of the population (2014), available at: https://www.vvsu.ru/analytic/article/10651389/ (Accessed 20.01.2021).

6. Statistical Yearbook of the Grodno region (2020), available at: https://grodno.belstat.gov.by/ofitsialnayastatistika/publications/public_compilation/index_18036/ (Accessed 15.10.2021).

7. Statistical Yearbook of the Brest region (2020), available at: https://brest.belstat.gov.by/ofitsialnayastatistika/publications/public_compilation/index_18060/(Accessed 18.10.2021).

8. Statistical Yearbook of the Vitebsk region (2020), available at: https://vitebsk.belstat.gov.by/ofitsialnayastatistika/publications/public_compilation/index_18040/(Accessed 21.10.2021).

9. Statistical Yearbook of the Gomel region (2020), available at: https://gomel.belstat.gov.by/ofitsialnayastatistika/publications/public_compilation/index_18043/(Accessed 24.10.2021).

10. Statistical Yearbook of the Minsk region (2020), available at: https://minsk.belstat.gov.by/ofitsialnayastatisticheskaya-informatsiya/publications/public_compilation/index_18073/(Accessed 27.10.2021).

11. Statistical Yearbook of the Mogilev region (2020), available at: https://mogilev.belstat.gov.by/ofitsialnayastatistika/publications/public_compilation/index_18039/ (Accessed 30.10.2021).

12. Bud'ko, O.N. and Bakhar, S.V. (2019), "The system of indicators and analysis of the standard of living of the population", Zbirnik nauk. prats' za materialami Mizhnar. naukovo-praktichnoï internet-konferentsii «Finansi, bankivs'ka sistema ta strakhuvannya v Ukraïni: stan, problemi ta perspektivi rozvitku v krizovïi ekonomitsi», DDAEU, pp. 166-168.

13. Bakhar', S.V. (2020), "Comparative analysis of the level of life of the population in the western regions of Belarus", Integration of practice and theory of scientific knowledge: materials of the VII scientific-practical conference with international participation of the North-West Institute (branch) of ANO VO MGEU, Murmansk, M.: MGEU, pp. 11-15.

14. Kim, J.-O., Mueller, CH.W. and Klekka, W.R. (1989), Faktornyi, diskriminantnyi i klasternyi analiz [Factorial, discriminant and cluster analysis], in Enyukov I.S. (ed.), Finansy i statistika, Moscow, Russia. 


\section{Аннотация}

Ольга Будько, Сергей Бахарь

\section{МНОГОМЕРНЫЙ СТАТИСТИЧЕСКИЙ АНАЛИЗ УРОВНЯ ЖИЗНИ НАСЕЛЕНИЯ БЕЛАРУСИ}

В статье на основе авторской системы показателей проведен сравнительный анализ уровня жизни населения в административных районах и областных иентрах Беларуси за 2019 год. С помощью метода главных компонент факторного анализа выявлены показатели, которые в наибольшей степени влияют на уровень жизни, вычислен интегральный показатель (индекс) уровня жизни населения, построен $u$ проанализирован рейтинг районов и областных центров. Даны рекомендации по улучшению уровня жизни. Методом k-средних кластерного анализа сформированы пять кластеров со схожим уровнем жизни населения. Проведен анализ сформированных кластеров как по средним значениям показателей, так и по районам областей. Сделан вывод о том, что по уровню жизни в 2019 году лидировала Брестская область.

Ключевые слова: уровень жизни, интегральный показатель, метод главных компонент, рейтинг, кластерный анализ.

\section{MULTIDIMENSIONAL STATISTICAL ANALYSIS OF THE STANDARD OF LIVING OF THE POPULATION OF BELARUS}

In the article, based on the author's system of indicators, a comparative analysis of the standard of living of the population in administrative districts and regional centers of Belarus for 2019 is carried out.

The system of indicators used includes indicators of six groups: demographic characteristics of the population, indicators of income, housing security, employment and unemployment, indicators of education and health.

The applied methodology is based on the methods of multivariate statistical analysis. The Statistica package was used for the calculations.

Using the method of the main components of factor analysis, the indicators that most affect the standard of living are identified. The integral indicator (index) of the standard of living of the population is calculated, the rating of districts and regional centers is constructed and analyzed. Recommendations for improving the standard of living are given. used.

Expert assessments are not used to construct the integral indicator, which is an important advantage of the method

Using the k-means method of cluster analysis, five clusters were formed with significantly different average values of the integral indicator: with a high, above-average, average, below-average and low standard of living of the population. The analysis of the formed clusters is carried out both by the average values of the indicators and by the districts of the regions. It is concluded that the Brest region was the leader in terms of the standard of living in 2019 , and the place in terms of the standard of living of the population of the other regions of the republic was determined.

Keywords: standard of living, integral indicator, principal component method, rating, cluster analysis. 